\title{
Costa Rica: Paradise in doubt
}

By: Fabrice Lehoucq

Lehoucq, Fabrice. "Costa Rica: Paradise in Doubt," Journal of Democracy, Vol. 16, No. 3 (July 2005): 140-54

Miquel Angel Rodriguez Echeverria Reply: “Getting Costa Rica Right,” Vol. 17, No. 2 (2006): 161-164.

Fabrice Lehoucq Reply: "Different Times, Different Demands," Journal of Democracy, Vol. 17, No. 2 (April 2006): 165-7).

Made available courtesy of Johns Hopkins University Press:

http://www.journalofdemocracy.org/

***Note: Figures may be missing from this format of the document

Long counted among Latin America's most stable and vibrant democracies, Costa Rica has now become a place where the once unimaginable happens. In just the past year, two former presidents of this Central American country of 4.3 million have been arrested on corruption charges, while a third has come under investigation. Voter turnout is dropping. Citizens are unhappy with the tone and content of public life. Agencies and boards responsible for policing the state seem to be working poorly. The public debt is growing to an unhealthy size. The party system, the link between citizens and the state, is disintegrating.

If left to fester, these problems could lay the groundwork for a gradual political implosion. There will be no military coup because the 1949 constitution bans a standing army, and more importantly, because the vast majority of Costa Ricans reject violence as a means of settling political disputes. If the political class does not reform key institutions and procedures, however, the party system will be unable to renew itself. If politicians bicker and social consensus begins to fray, it is not far-fetched to imagine an irresponsible populist becoming influential. This prospect leaves many Costa Ricans fearing for the future of their country.

A robust economy - real Gross Domestic Product was thought to be growing at a yearly rate of 5.6 percent as recently as 2003 - plus the political system's underlying strengths should permit a political recovery, but it is unlikely to be either quick or painless. Citizens must use their votes and other lawful means of influence to persuade the parties to embrace a raft of reforms. First, the parties need to start holding roll-call votes in the Assembly, a practice that they have resisted for decades, to be held accountable. [

Next, the parties will need to overhaul their internal operations and rethink the ways in which they relate to society. This will involve getting politicians to hold public hearings on how they appoint the supervisory boards that run a large and complex state apparatus - an appointment process deliberately kept in the dark for decades. Getting the parties to transform largely ineffective campaign-finance laws will require party leaders to end the secrecy surrounding the 
manner in which they spend public as well as private campaign funds. Finally, getting the parties to build a consensus calling for tax hikes, spending cuts, or some combination of the two will force citizens and the state to begin choosing among and ranking goals and interests in a more coherent way.

These and other accountability-enhancing reforms promise to rebuild the body politic, and by the same token will demand changes dramatic enough to generate opposition and conflict. Fear of a populist takeover will hopefully serve both to keep minds focused on the need for serious change, and help to spur the creation of strong institutional safeguards against corruption, influence-peddling, and the like.

The degree to which such ills might be troubling Costa Rica hit home on 22 October 2004, when citizens were treated to the spectacle of former president Rafael Angel Calderón (1990-94) of the center-right Social Christian Unity Party (PUSC) going to jail in handcuffs. He faced charges of having taken a US $\$ 450,000$ kickback from a loan of almost $\$ 40$ million that the Finnish government had made to Costa Rica's Social Security Institute in order to finance the Institute's purchase of medical equipment. Calderón's critics professed themselves unsurprised, as they had long complained that he shared the corrupt tendencies that these critics imputed to his father, who had been president back in the early 1940s. Moreover, La Nación of San José, the country's leading newspaper, had been reporting for months that the younger Calderón was a target of the Costa Rican general attorney's investigation into influence-peddling rackets.

At any rate, a larger shock had come a week earlier. A former president of more recent vintage, Miguel Angel Rodríguez (1998-2002) also of the PUSC, had stepped down from his freshly assumed post as secretary-general of the Organization of American States (OAS) and had flown back to San José to face manacles and judicial detention on bribery charges. Rodríguez stands accused of having accepted a \$1.2-million payoff from the giant French telecommunications firm Alcatel in order to help it win a large contract from ICE, Costa Rica's state-run electricity and communications company. Rodríguez boasts an impressive nonpolitical resume as an accomplished economist and successful businessman, which caused many to wonder how he had become involved in the ICE-Alcatel affair along with his close associate, ICE executive director José Antonio Lobo. Soon after, an investigative committee of the Assembly accused former president José Figueres, Jr., (1994-98) of influence-peddling. Figueres, a president from the center-left National Liberation Party (PLN), had been executive director of the World Economic Forum in Davos, Switzerland, since 2000. In October 2004, he was forced to resign when Forum officials learned that he had failed to report a large consulting fee that he had received from a private telecommunications firm. As of this writing in early June 2005, neither Rodríguez nor Calderón has been found guilty of any of the crimes for which they were detained, and both have been permitted house arrest. Nor is it clear what the Assembly will do with former president Figueres, who has refused to return to Costa Rica to defend himself.

These high-profile investigations and arrests show that public prosecutors are taking their mandates seriously enough to enforce the rule of law. They also have political support for doing so: The Legislative Assembly and incumbent president Abel Pacheco of the PUSC furnished the general attorney's office with additional funding in November 2004. The anticorruption campaign has crystallized public discontent that has been manifesting itself in a variety of ways. 
Among these is falling turnout in elections, which in Costa Rica occur every four years and take place during the same calendar year to fill both the presidency and all the seats in the 57-member Legislative Assembly. While turnout in general elections had averaged around 80 percent for decades, in 1998 it took a 10 percent dip and stayed there in 2002. While Costa Rica's current turnout rate of around 70 percent is still comparatively robust, the decline in overall participation has not only been noticeable, but has gone hand-in-hand with a dramatic drop in the aggregate share of the popular vote that the two major party formations can claim. In the five elections held between 1982 and 1998, the PLN and the PUSC accounted for an average combined vote share of 92 percent. In 2002, by contrast, just 63 percent of voters supported one of those two parties.

The average proportion of voters calling themselves independents, meanwhile, rose from a low of 17.1 percent during the presidency of Oscar Arias (1986-90) of the PLN to a high of 30.8 under President Rodríguez (these figures are averages of quarterly polls done jointly by the Gallup organization and the Center for the Investigation of Democracy). After the 2002 elections, the average "effective number" of parties in the legislature rose to 3.7 from a previous average of 2.5 that had held steady for most of the preceding five decades. In a December 2004 survey, only 9 percent of respondents said that they were hoping for a PLN victory in the 2006 elections, while an even smaller number (5 percent) said the same thing about the PUSC. ${ }^{1}$

Of all the political systems in Latin America, Costa Rica's is arguably one of the best. ${ }^{2}$ The 2002 average of the World Bank's six "governance indicators" places Costa Rica in the 77th percentile, some 22 percentile points higher than comparable countries in the region and 14 points higher than the average country in Costa Rica's income category worldwide. The 2003 Bertelsmann Management Index (BMI), a composite measure designed to rank a polity's ability to build agreements to solve social problems, ranks Costa Rica as the eighth most successful on a list of 116 developing countries. In Latin America, only Chile (third on the same list) and Uruguay (sixth) receive comparable ratings from the BMI. ${ }^{3}$

Widely used indices of development also rank Costa Rica favorably. Between 1950 and 2000, the country's GDP per capita increased fourfold, going from $\$ 847$ to $\$ 3,315$ (both figures are in 1990 U.S. dollars) — a stellar performance in a region where GDP per capita barely doubled during the same period. According to the World Bank's 2004 report on socioeconomic inequality in Latin America, Costa Rica maintained throughout the 1990s a Gini Index coefficient below 0.45 (a Gini number of 0 signifies absolute equality of income distribution, while a 1 indicates absolute inequality). This means that Costa Rica, along with Uruguay, has one of the most level income distributions in Latin America.

\section{The Tican Achievement}

Costa Rica has had a competitive political system for more than a hundred years, and has been a democracy for almost the last fifty of those. Before the 1950s, hotly contested elections were often marred by force or fraud. Serious improvement began in the late 1940s, when incumbents and oppositionists finally agreed to strip both the executive and legislative branches of electoralsupervision powers and instead made an independent court system solely responsible for organizing elections and tallying votes. ${ }^{4}$ 
The advent of full democracy (a system wherein all political forces can compete openly for elected office under conditions of universal adult suffrage) may fairly be dated to the late 1950s, when the losers of the 1948 civil war came back from exile and began running for office again. Since the 1958 presidential election, which saw the PLN incumbent reluctantly concede defeat, executives and legislators have come to power in elections that are held regularly every four years and are renowned for their openness and fairness.

Between 1949 and 2002, average turnout exceeded 77 percent of the adult population. Not only have elections been fraud-free, but they also have been close and hard-fought. Between 1953 and 1978, the PLN enjoyed something approaching hegemonic status. It lost the presidency only on the rare occasion when enough of its rivals got behind a joint ticket. After President Rodrigo Carazo (1978-82) of the Christian Unity party (a PUSC forerunner) defaulted on the country's foreign debt, the PLN won two elections in a row before starting to lose by narrow margins of little more than 3 percent or so between 1990 and 2002.

Since 1936, Costa Rica has used a qualified form of majority rule to elect its president. This method requires the winner to obtain more votes than any single rival and to win at least 40 percent of all valid votes cast. This encourages parties to seek the support of the median voter and to coalesce into two partisan blocs. My calculations suggest that the winner in all but three of the thirteen presidential races held since 1953 has been the candidate who appealed most successfully to the median voter - the voter at the exact center of the political spectrum. ${ }^{5}$ The 40 percent threshold spurs parties to work for large numbers of votes, which in turn fosters a twoparty system or something fairly close to it.

This dynamic has meant the rise of a unified opposition to challenge the long-dominant PLN as a peer-competitor. The ascent of the PUSC to this role received an important boost under President Luis Alberto Monge in the early 1980s. Anxious to rally opposition legislators behind his emergency economic measures and structural reforms, Monge endorsed a change in the Electoral Code that allowed the recently formed PUSC to obtain the shares of public campaign financing owed to its constituent parties, which had run separate tickets in previous elections.

The use of proportional representation (PR) to elect the Legislative Assembly produces a median deputy who more or less echoes the preferences of the median voter. Electoral laws based on PR principles ensure that a chamber consisting of 57 representatives elected in seven multimember districts reflects the views and diversity of tastes found in society at large. Along with the qualified majority-rule system for electing the president, the system of representation keeps elected officials relatively well-informed regarding changes in public opinion and political preferences.

Political scientists have long admired Costa Rica as a case of successful presidential democracy. While there have been standoffs between the executive and legislative branches, these have never been the occasion for an autogolpe (executive coup) or other form of presidential assault on the political system. On the one hand, the practice of holding elections for president and all 57 Assembly seats on the same day often gave voters an opportunity to choose legislative majorities sympathetic to the president's platform. 
On the other hand, however, the ban on consecutive terms for legislators as well as presidents means that legislative support for the executive tends to drop as general elections draw near. Term limits make lame ducks out of presidents by the third year of the four-year term as deputies, even from the progovernment party, distance themselves from the incumbent. Legislators focus instead on aligning themselves with a future president, hoping perhaps for a cabinet or senior bureaucratic post in the new administration, or for an advantage in the world of local government and politics.

The electoral cycle helps to keep presidents weak. As legislative support for the presidential agenda dips, moreover, conflict between the elected branches of government becomes more likely. My own research shows that vetoes are more than twice as likely to occur during periods of divided government- 12 percent of the time versus less than 5 percent during periods of unified government. Similar work shows that during the last year of a term, presidential bills often fail even to make it out of committee. ${ }^{6}$

A relatively even distribution of powers between the elected branches of government, along with "fast-track" budget procedures, means that the scope for confrontation is limited. The president has no power to call referenda on his own and only restricted decree-issuing powers. The 1949 constitution also lays down special budget-enacting procedures that prevent both branches from holding the budget hostage. The executive must submit a budget by September 1, and the Assembly must pass one within ninety days after that date. While the legislature can amend the budget bill, the executive cannot veto it - the sole exception to the president's ability to apply this check to legislative acts.

Among the most remarkable features of the Costa Rican political system is the degree to which it gives important policy-making responsibilities to a set of autonomous institutions. Health care, old-age pensions, monetary policy, and electoral supervision are among the policy areas under the purview of bodies whose budgets the executive does not propose and the legislature does not approve. Many have earmarked sources of funding so that, for example, payroll deductions finance health care and old-age pensions while telephone and utilities charges fund ICE, the Costa Rican Institute of Electricity. In terms of their size, the more than a hundred autonomous institutes (which include state-owned banks) control monies rivaling the central state apparatus (the three branches of government plus the Supreme Tribunal of Elections). The judiciary, independent under the 1949 constitution, has since 1989 featured a Constitutional Chamber that has become an assertive interpreter of the powers that each branch of government possesses as well as an arbiter of the boundaries between them. ${ }^{7}$

\section{The Roots of Political Decay}

Perhaps the seminal event of modern Costa Rican political history was President Carazo's 1982 decision to default on the national debt. His government's refusal to let the exchange rate float at a time of burgeoning fiscal and trade deficits had caused public indebtedness to more than double in just a year, going from a sum equivalent to 56.2 percent of annual GDP in 1980 to one equaling 125.2 percent of GDP in 1981. Restoring Costa Rica's credit required an export-led development policy that rendered meaningless most skirmishing between the left-leaning PLN and its right-of-center adversaries. By the 1990s, an increasingly educated and urban electorate began to demand more transparency and accountability from the recent development of a two- 
party system, one that had begun to collude against the public interest in various ways, even as debt-servicing obligations straitjacketed the government's ability to address deep social problems or to invest for future growth.

\begin{tabular}{|c|c|c|c|c|c|c|}
\hline \multirow[b]{2}{*}{ YeAR } & \multicolumn{3}{|c|}{ Legislative } & \multicolumn{3}{|c|}{ Presidential (ny Party) } \\
\hline & PLN & PUSC & Other & PLN & PUSC & Other \\
\hline 1986 & 48 & 42 & 11 & 52 & 46 & 2 \\
\hline 1990 & 42 & 47 & 11 & 47 & 51 & 2 \\
\hline 1994 & 45 & 40 & 15 & 50 & 48 & 2 \\
\hline 1998 & 34 & 41 & 25 & 44 & 47 & 9 \\
\hline 2002 & 27 & 30 & 43 & 31 & 39 & 26 \\
\hline
\end{tabular}

Sources: IFES Election Guide, www,electionwatch.org and Tribunal Supremo de Elecciones de Costa Rica.

By 2002, voters had had enough. That year, a breakaway PLN faction called the Citizen Action Party (PAC) took 25 percent of the legislative vote. Then, for the first time since 1936, no presidential candidate met the 40 percent threshold and a runoff had to be held. In total, parties aligned with neither the PLN nor the PUSC obtained 37 percent of the vote and a like share of seats in the 2002 Assembly elections. (See the table above.)

Dissatisfaction with the political establishment surfaced in several ways. The first was a decline in expressed support for the political system (not to be confused with democracy as such) in opinion polls. ${ }^{8}$ On a scale from 1 (low) to 7 (high), support for the political system peaked at 6.7 in 1983 before falling steadily and reaching 5.5 in 1999. The second sign of discontent was the already discussed phenomenon of falling turnout. Finally, in surveys spanning 2001 and 2002, only 7.8 percent of respondents between 17 and 25 years of age, and only 36.9 percent of older adults, were willing to approve Costa Rica's two-decade-old two-party system. ${ }^{9}$

In an economically dynamic society with better-schooled and better-informed voters than ever before, traditional party leaders have been slow to keep pace. Until the 1990s, they saw to it that nominating conventions for legislative candidates were largely ceremonial. Presidential primaries began in 1978, but neither of the two big parties adopted legislative primaries. While the Electoral Code calls for party caucuses at the district, cantonal, and provincial levels to choose candidates, these meetings were easily subjected to manipulation. The Supreme Tribunal of Elections did not even begin sending monitors until 1988, and then only to each party's provincial and national caucus meetings (Costa Rica has 7 provinces, 81 cantons, and 510 districts).

The PUSC has done a smoother job of integrating democratic elements into its candidateselection process. While both parties hold presidential primaries, followed by party conventions tasked with approving legislative candidates that the presidential nominees choose in conjunction with other party notables, the PLN has found itself riven by factional disputes over how large a candidate-selection role rank-and-file members should play. Before the 1998 elections, PLN reformers publicly fought the party's leadership all the way to the Constitutional Court over this 
issue. The PUSC, by contrast, suffered no such rifts. Its leaders modified their closed-list system in 1995 by requiring all legislative nominees to obtain at least 40 percent support within cantonal — or municipal — assemblies in order to be eligible for nomination by the national convention.

The recent decay of the two-party system has made governance much more complicated than before. The qualified-majority system for choosing the president may have bred a centrism so bland that it has alienated large chunks of voters who wish to see the parties advocate sharper agendas. By the early 1990s, the complaint that the PLN and PUSC were mirroring each other had become a common refrain. Many citizens felt unrepresented by either, and wanted more say in choosing candidates as well as a system more open to new ways of dealing with large issues such as the national debt. In a more educated society, personalism could not fill the ideological void as fully as it once had, not least because the old days of personalismo were also a time of fairly sharp ideological debate between the PLN and its rivals.

\section{The Failure of Horizontal Accountability}

Much of what the Costa Rican state does goes on outside of executive ministries. Creating the decentralized sector or the autonomous institutions was part of the 1949 Constituent Assembly's broader effort to remove as much as possible of the functions of the modern state from the partisanship of the elected branches of government. Thanks to this sector, virtually the entire population enjoys basic services including health care, higher education, water, and telecommunications. Autonomous institutions have programmatic and budgetary autonomy; they often have specific or protected revenue sources and their annual budgets require neither executive nor legislative approval.

By the mid-1990s, there were more than 118 such autonomous institutions. Unlike the three branches of government and the electoral tribunal, their budgets are not part of the central state budget. Only the Office of the Comptroller General checks their budget to make sure that they are complying with the law. These bodies include state corporations (though not all state corporations are autonomous institutes) and a host of agencies charged with fulfilling an array of ambitious development objectives.

Perhaps the most prominent of these is the Board of National Social Security, founded in 1943. By the 1990s, this institution had come to be the primary provider of medical care to nearly 68 percent of the salaried and unsalaried economically active population and their families. Other important autonomous institutes include the now scandal-tinged ICE, which has provided electricity and telephone service since its founding in 1949. In 1950, the combined budgets of such bodies equaled 7.3 percent of GDP. By 1994, that figure was probably close to 20 percent-as much as central government spending at the time. ${ }^{10}$

By the 1960s, politicians were becoming concerned that such a large portion of the state budget was outside their control. Beginning in 1968, the Assembly passed a series of constitutional changes that left the administrative autonomy of these bodies intact while abolishing their ability to exempt themselves from state directives concerning the governance of the public sector as a whole. A 1970 law cut the terms of these bodies' board members from seven to five years and allowed each new Costa Rican president to name only four out of seven board members for each 
body (rather than all seven, as before) while handing the right to appoint the remaining three to the party that finished second in the presidential race. In 1974, the president received the power to name chief executives for many of these decentralized agencies.

Yet by the 1980s, there were good reasons to ask whether bipartisan collusion had undercut the institutional mechanisms for ensuring that these agencies were fulfilling their mandates. As differences between the PLN and the PUSC eroded, they began to collude at the task of colonizing the autonomous bodies with their respective loyalists. The board seats and presidential offices of these bodies began to fill up with former deputies, ambassadors, and mayors; campaign contributors; and members of the president's coterie. Often these people had little or no experience at or interest in running complex bureaucracies, or worse yet, displayed serious conflicts of interest.

The effects of flawed mechanisms of horizontal accountability are perhaps best illustrated by the case of the Anglo-Costa Rican Bank (BAC), the country's oldest fiduciary financial institution. One study shows how anxious the BAC's supervisory board had become by the 1980s to shield itself and its appointee, the bank manager, from outside scrutiny. ${ }^{11}$ The BAC repeatedly refused requests for information from the office of the General Auditor of Financial Entities, another decentralized institution. The auditor's staff had wanted to look into matters such as the BAC's unprecedented and illegal incorporation of part of itself in Panama, its loans to influential PLN and PUSC figures, its illicit loans to political campaigns, and its purchase of dubious Venezuelan bonds. When the scale of the bad loans that the BAC was carrying became public knowledge, depositors began fleeing in panic until the president and the Assembly stepped in to halt the losses by closing the bank's doors and liquidating its assets in 1994. According to the Economic Commission of Latin America, handling this foreclosure caused Costa Rica's fiscal deficit to expand by 14 percent.

The Office of the Comptroller General is the watchdog which, on behalf of the Assembly, guards the executive branch and the autonomous bodies alike. While nobody questions the professionalism of the comptroller's staff, neither the Assembly nor the comptroller's office is known for being an aggressive guardian of the public interest. The latter in particular has run into criticism for taking an overly narrow, bookkeeperish view of its duties. One study, for instance, documents how little both the comptroller's office and the Supreme Tribunal of Elections do to verify the accuracy of the receipts that parties submit for reimbursement under the laws establishing public campaign financing. On the fairly rare occasions when parties are caught with their books out of order, the study further shows, the comptroller does little to penalize them. ${ }^{12}$

These case studies reveal why Costa Ricans are so upset with their country's political class. Despite the widespread and somewhat reasonable assumption that Costa Rican public life is honest by world and regional standards, hard evidence to support this notion is hard to find. What is clear is that Costa Ricans believe their public officials are corrupt: According to surveys, 75 percent of Costa Ricans believe that corruption is somewhat or very generalized among public officials. This is the highest rate among the five Central American countries plus Colombia, Mexico, and Panama, even though Costa Rica ties with Colombia for the lowest share of respondents (15 percent) who say that they have experienced at least one act of corruption per year. $^{13}$ 


\section{Crippling Fiscal Deficits}

Renewing a bankrupt party system and improving horizontal accountability will prove tasks complex enough to keep officials busy for years. Unfortunately, they must make these repairs to a ship of state that is tossing on increasingly turbulent waters while running dangerously low on fuel. Though the public sector no longer has a huge external debt with which to contend, it is running short of funds just when it needs them to rebuild itself.

While the Costa Rican government has always run a fiscal deficit, prudent monetary policy and positive capital-account inflows from 1961 to 1980 kept the public debt at slightly less than a quarter of annual GDP, well below the 60 percent ceiling recommended for developing economies. Consumer-service charges levied by autonomous agencies such as the Social Security Institute and the Water Commission partly offset low tax yields. Around the time of the 1982 debt default, however, the deficit was beginning a sharp upsurge that would see it balloon as high as 96 percent of GDP before falling below 60 percent again in $1992 .{ }^{14}$

Underlying these fiscal problems is the awkward and hard-to-sustain situation of a society that is trying to provide its people with first-class social programs on the basis of a rickety Third World tax system. The lack of serious policy dispute between the two major parties only makes the problem worse by obscuring it. Costa Rica has a public sector (meaning the "regular" central and municipal levels of government plus the autonomous bodies) that consistently spends far more than 15 percent of GDP, but which (like most developing-world states) can never manage to collect more than 12 or 13 percent of that same GDP in the form of tax revenues. The demands of meeting the resulting shortfall every year have led officials to cut public investment and the public payroll, as well as contract series of internal and foreign debts that by 2003 totaled close to 60 percent of annual GDP. Currently, almost a third of the money that the central government spends goes to pay the interest on the public debt. ${ }^{15}$

Incumbent president Abel Pacheco commissioned an independent report on fiscal reform soon after taking office in 2002, and in 2003 managed to get a reform bill introduced in the Assembly. It remains there, unenacted, at the time of this writing in early June 2005. Until the government and the citizens agree on decisive action to improve tax-collection rates and pay for public services, increasing numbers of voters will see their policy demands go unfulfilled and have yet another set of reasons to punish parties at the polls.

\section{What Might the Future Bring?}

While the ex-presidential scandals may have thrust Costa Rica into world headlines for a day or two, the country is more often taken for granted as a peaceful, democratic Third World success story. But whatever the outcome of the cases against the onetime chief executives, the scandals have made it obvious that not all is well in Costa Rica.

While the country's political system has reserves of strength, public opinion is correct to sense that the body politic is deeply ailing. An innovative political architecture, one that delegates many functions of the central state to institutions which are largely independent of the executive and legislative branches of government, has succumbed to bipartisan cronyism and bureaucratic inertia. The two major parties are losing their grip because they have failed to open up sufficiently. And neither citizens nor officials have taken seriously enough the effects on basic 
public services (a key part of governance) or long-term macroeconomic health of a fiscal policy devoted to spending without adequate revenue collection to pay the bills.

What is going to happen? One possible scenario is bleak: The two-party system will completely disappear with the 2006 elections. The Assembly will become more political novices.

Disagreements between the executive and the legislature will paralyze policymaking. Public support for the political system will continue to fade. There will be no political consensus behind any particular combination of spending cuts, tax hikes, and measures to improve tax collection. The size of the public debt will continue to grow and servicing it will consume an ever-larger share of stagnant revenues. Public-sector strikes will further degrade the quality of public services. Economic growth will droop, as will investment. With some changes, this is essentially the same route that led to the collapse of democracy in Uruguay in 1973 and to its implosion in contemporary Venezuela.

There is some evidence for this scenario. In mid-2000, university students, ICE workers, and other public-sector employees paralyzed the country with a strike designed to block reform of the ICE. Protestors claimed that the government was planning to privatize the Commission. President Rodríguez's administration argued that the ICE-workers' union was preventing changes necessary to make electricity and telecommunications more competitive. ${ }^{16}$ With the breakup of the PAC in 2004, the effective number of parties is now more than four. The 2006 elections will very likely return an equally fragmented party system to the Assembly. This will both increase the representativeness of the Assembly, but will also - at least until the key players learn to adapt - slow the policy-making process. When public-sector works staged a fresh wave of strikes in mid-2004, President Pacheco's decision to meet their wage demands led his finance minister to resign and fiscal reform to stall yet again.

An alternative scenario is that stress and even crisis will spur a political renewal built on a different party system. This is not the first time that Costa Rica's political model has come under severe strain. Polarization and institutional breakdown sparked the 1948 civil war, but without that conflict the transformation embodied in the 1949 constitution would probably never have occurred. The 1982 debt default led to a major reorientation in development strategy and the rise of the now nearly dead two-party system. Two decades after that economic collapse, citizens are demanding an overhaul of the systems of representation and horizontal accountability.

Costa Rica's people and politicians have shown in the past that they can learn from mistakes and rebuild their political system. So far, that system - or at least its character as a law-governed democracy - retains the support of its citizens. There is no support for authoritarian solutions; according to Latinobarómetro surveys, Costa Ricans still overwhelmingly favor democracy. ${ }^{17}$ Nor is the political system wholly deaf to changing popular preferences and expectations. While efforts to democratize the PLN and PUSC candidate-selection processes may have met mostly with disappointment so far, the larger push to deepen citizen participation remains a going concern.

Indeed, this new stress on finding a more active role for people to play in their own governance may be the single most important and understudied development in contemporary Costa Rican politics. ${ }^{18}$ Both parties have supported municipal decentralization as well as community 
participation, and continue to tinker with their methods for choosing Assembly candidates. Moreover, the use of proportional representation in elections for the Assembly allows disgruntled citizens to give third parties a chance to rectify political problems.

Already, the Assembly has begun to respond. In late October 2004, it passed Costa Rica's first law specifically aimed at fighting public corruption. Also in late 2004, legislators voted to dismiss Comptroller General Alex Solís for having forged the signatures of relatives (with their consent) on checks. This is a sign that Costa Rican politicians may be ready to demand nothing but the highest behavior from each other. A healthy next step would be for the Assembly to overhaul the procedure for choosing the top executives and board members of the autonomous bodies. The Assembly also needs to hold roll-call votes to improve transparency and political accountability. It needs to enact new campaign-finance legislation to restore faith in discredited parties. Most importantly, it needs to initiate an ample and thorough debate about how to raise chronically low tax rates and what the priorities of state spending should be.

In what may turn out to be a significant contrast with Uruguay in the early 1970s and Venezuela today, Costa Rica is currently enjoying real gains in national wealth. Behind the growth, moreover, lies an open and well-diversified economy and a society that can protect and increase incomes. An equally autonomous society should also be able to demand that citizens take part in modernizing their own political system.

For advocates of serious political renewal, the crucial date may be 2006, the year of the next general elections. President Pacheco, who cannot run again, has proven a passive figure who mostly seems to watch rather than shape events. His poll ratings and legislative support are anemic. Some observers have criticized him for taking the eccentric position that he will not send the Central American Free Trade Agreement (CAFTA) to the Assembly until he is convinced that all Costa Ricans will benefit from the accord and until the Assembly adopts a fiscal-reform package. Meanwhile, the rest of Central America is approving CAFTA.

In retrospect, the Costa Rican political system has displayed glaring weaknesses as well as notable strengths. Along with typically favorable cross-national comparisons, a dearth of systematic research made it all too easy to overfocus on the strengths and underfocus on the weaknesses. After half a century of conflict and debate, incumbents and opposition movements did create a full-blown democracy. The country's hierarchically organized and closed political parties, while they have now shown themselves no longer functional for an educated and demanding electorate, did nonetheless ease the way to constructive long-term agreements on key aspects of development policy. The ease of relations between the parties, however, also opened the door to partisan collusion and violations of the public interest, as the recent scandals show. Reasonable levels of economic growth and the resilience of the political system should permit a slow and hard-fought political recovery. If things go especially well, politicians and citizens may even learn how to create effective institutional safeguards against corruption and influencepeddling, to name two of the most serious afflictions affecting political systems in lessdeveloped and unequal societies.

\section{Endnotes}


The author thanks Gilberto Arce, Ciska Raventós, Juan Carlos Rodríguez, Fernando F. Sánchez, and Jorge Vargas for answers to numerous questions. Any observer of Costa Rican politics must also express a debt of gratitude to the Programa del Estado de la Nación and the Academia de Centroamérica for their research, data, and websites. Finally, I thank Aida for helping in too many ways to list.

1. See www.nacion.com/ln_ee/diciembre/14/870357.jpg. Data on the number of independents stems from Fernando F. Sánchez, "Dealignment in Costa Rica: A Case Study of Electoral Change," doctoral diss., University of Oxford, 2003, 190. See also Jorge Rovira Mas, ed., La democracia de Costa Rica ante el Siglo XXI (San José: Editorial de la Universidad de Costa Rica, 2001), 195-231.

2. John A. Booth, Costa Rica: Quest for Democracy (Boulder, Colo.: Westview, 1998) emphasizes political culture. Fabrice Lehoucq, Lucha electoral y sistema político en Costa Rica, 1948-1998 (San José: Editorial Porvenir, 1997) gives importance to institutional arrangements. Bruce M. Wilson, Costa Rica: Politics, Economics and Democracy (Boulder, Colo.: Lynne Rienner, 1998), discusses issues of political economy.

3. Bertelsmann Foundation, Bertelsmann Transformation Index 2003: Political Management in International Comparison (Gütersloh, Germany: Bertelsmann Stiftung, 2004). The World Bank rankings stem from Daniel Kaufmann, et al., "Governance Matters III: Governance Indicators for 1996-2002," World Bank Policy Research Working Paper 3106, Washington, D.C., 2003.

4. Fabrice Lehoucq and Iván Molina, Stuffing the Ballot Box: Fraud, Reform, and Democratization in Costa Rica (New York: Cambridge University Press, 2002).

5. Fabrice Lehoucq, "Costa Rica: Modifying Majoritarianism with a 40 Percent Threshold," in Josep M. Colomer, ed., Handbook of Electoral System Choice (London: Palgrave-Macmillan, 2004).

6. Fabrice Lehoucq, "Policymaking, Parties, and Institutions in Democratic Costa Rica," paper presented at the conference "Reform of the State and the Policymaking Process (IPES 2005)," Inter-American Development Bank, Washington, [End Page 153] D.C., February 2005. For the first empirically based discussion of the effects of term limits on presidential success, see Michelle Taylor-Robinson, "The Effect of Party Candidate Selection Procedures and National Electoral Rules on the President's Ability to Achieve His Legislative Agenda: The Case of Costa Rica," paper presented the UNT Conference on Parties and Elections in New Democracies, Dallas-Fort Worth, 12-13 April 2002. The point about deputy incentives comes from John M. Carey, Term Limits and Legislative Repre sentation (New York: Cambridge University Press, 1998), 98.

7. Bruce Wilson, Juan Carlos Rodríguez, and Roger Handberg, "'The Best-Laid Schemes . . . Gang Aft A-Gley': Judicial Reform in Latin America-Evidence from Costa Rica," Journal of Latin American Studies 36 (August 2004): 507-31.

8. Mitchell A. Seligson, "Trouble in Paradise? The Erosion of System Support in Costa Rica, 1978-1999," Latin American Research Review 37 (Spring 2002): 160-85.

9. Surveys cited in Fernando F. Sánchez, "Dealignment in Costa Rica," 313. The next paragraphs also draw upon Sánchez, 219-333.

10. James W. Wilkie, "Recentralization: The Budgetary Dilemma in the Economic Development of Mexico, Bolivia, and Costa Rica," in James W. Wilkie, ed., Statistics and National Policy (Los Angeles: UCLA Latin American Center, 1974); and Thelmo Vargas Madrigal, "¿Qué queremos, y qué no, del Estado?" Revista Parlamentaria 3 (August 1995): 53-70. 
11. Ciska Raventós, "Las fallas del estado de derecho: corrupción y baja calidad de la democracia en Costa Rica," unpub. ms., 2004.

12. Kevin Casas-Zamora, Paying for Democracy: Political Finance and State Funding for Parties (Colchester, United Kingdom: ECPR, 2005).

13. Jorge Vargas-Cullel and Luis Rosero-Bixby, La cultura política de la democracia en Costa Rica, 2004 (San José: EUCR, 2005), 60-66. The source for the data in this survey is the Latin American Public Opinion Project (LAPOP) directed by Mitchell A. Seligson at Vanderbilt University.

14. Andrés Rodríguez-Clare and José Angulo, "El sistema tributario y aduanero: una visión del conjunto," in Contraloría General de la República, El sistema tributario costarricense (San José: Contraloría General de la República, 2002), 18. All other data are from Carmelo Mesa-Lago, Market, Socialist, and Mixed Economies: Comparative Policy and Performance in Chile, Cuba, and Costa Rica (Baltimore: Johns Hopkins University Press, 2000), 508-10.

15. Fabrice Lehoucq and Iván Molina, Stuffing the Ballot Box.

16. Bert Hoffman, The Politics of the Internet in Third World Development: Challenges in Contrasting Regimes with Case Studies of Costa Rica and Cuba. (New York and London: Routledge, 2004), 100-14.

17. "An Alarm Call for Latin America's Democrats," Economist, 26 July 2001.

18. See Proyecto del Estado de la Nación, Auditoría Ciudadana sobre la Calidad de la Democracia (San José: Proyecto del Estado de la Nación, 2001) for a comprehensive look at citizen complaints about their political system. 


\section{Getting Costa Rica Right}

\section{By: Miguel Angel Rodriguez Echeverria}

Article Reply: “Getting Costa Rica Right,” Vol. 17, No. 2 (2006): 161-164.

Fabrice Lehoucq's July 2005 essay in these pages, "Costa Rica: Paradise in Doubt," analyzes the deterioration of politics and political parties in Costa Rica over the last 15 years. In the last paragraph of the article, Lehoucq concludes:

The country's hierarchically organized and closed political parties, while they have now shown themselves no longer functional for an educated and demanding electorate, did nonetheless ease the way to constructive long-term agreements on key aspects of development policy. The ease of relations between the parties, however, also opened the door to partisan collusion and violations of the public interest, as the recent scandals show. ${ }^{1}$

This hypothesis has a fundamental problem. If the Costa Rican system worked well up until about 1990 (Lehoucq does not give an exact date, but this is the drift of his analysis) and has deteriorated since, surely the cause must be something that began to exert its effect around that time. To cite the ability of the two major political groupings regularly to reach agreements on policy and to implement such agreements in the Legislative Assembly is to name a peculiar culprit. How can something that had been present for many decades suddenly become the cause of recent problems? Moreover, if the "ease of relations between the parties" leads to collusion, corruption, and political deterioration, how can we explain the relative health and effectiveness of the political systems in the United States, Great Britain, and many other European countries? Surely, one cannot postulate a hypothesis to explain one case and neglect its counterfactual implications for other cases. In fact, I would argue precisely the opposite-namely, that it has been precisely the failure of the two main political parties to reach and implement agreements that has caused Costa Rica's recent political problems.

Until the early 1990s, agreements between the two main political organizations in Costa Ricaone essentially Social Democratic and the other Christian Democratic - kept the system functioning well. The signs of success included an illiteracy rate that dropped from 21.2 percent in 1953 to 6.1 percent in 1990, an incidence of infant mortality that fell from 90.2 per thousand births to 14.8 per thousand over the same period; an average life expectancy that shot up from 55.6 to 74 years; pensions that went from covering almost no workers to covering almost half the workforce; and health-insurance coverage that became universal. ${ }^{2}$ To a significant degree, these achievements rested on a rule that allowed two-thirds of the Assembly to end debate on a measure and put it to a vote. Of equal importance, during much of this period party leaderships were strong - in no small part because the possibility of reelection helped to lend them continuity - and they could make deals that would let the governing party reach a final vote on major legislation.

The 1969 constitutional amendment that banned presidents from immediate reelection and banned legislators from serving consecutive terms sapped this deal-making capacity, while a 1981 change in the Assembly's procedures ended the power of a two-thirds majority to force a 
vote. At first this meant little. Center-left governments from the Party of National Liberation (PLN) were in office from 1982 to 1990, during which time the center-right Social Christian Unity Party (PUSC) was in the process of forming out of what had previously been a coalition. Conditions for interparty collaboration were strong - the PUSC's leaders needed PLN support for changes in the electoral code that would make PUSC unity viable — and cooperation extended so far that PUSC legislators cast the votes needed to pass several of the difficult and often unpopular structural reforms that stabilized the economy and reignited growth after the 1981 debt crisis. While those measures were consistent with the ideological principles and pragmatic proposals of PUSC, it is hard to imagine such considerations mattering in today's harsher political climate. Clearly, the "ease of relations" between the parties during the 1980s was crucial in enabling the PUSC to support the economic agenda of PLN governments.

During the presidency of the PUSC's Rafael Angel Calderon (1990-94), the institutional changes of the previous years began to make their full influence felt. It was also during this period that the new Constitutional Court began to enforce formal Assembly procedures, including the 1981 changes, which had previously often been ignored in practice.

With reelection banned, the struggle for the top spot in each party has become constant and consuming. While Lehoucq is correct to point out that the need to attract at least 40 percent of the popular vote in order to win the presidency encourages a focus on the median voter nationwide, ${ }^{3}$ this does not apply to leadership elections within each party. Instead, internal competition within a center-left party tends to give an edge to partisans who tilt left, making it risky for politicians who want that party's presidential nomination to make concessions to centerright proposals. This dynamic explains why Costa Rica, which the Inter-American Development Bank (IADB) considered an "early reformer" in the 1980s, saw the PLN kill "structural adjustment" in the 1990s. From 1994 to 1998, PUSC legislators again lent their support to such unpopular measures as streamlining the teachers' pension system, only to see the PLN, moving left in the midst of the inevitable leadership struggle, undercut the PLN administration of President José Figueres, Jr.

While I was president from 1998 to 2002 , I tried to circumvent the partisan wrangling in the Assembly by means of a national consensus-building process known as the Concertación. While this approach of working with civil society at first seemed to be succeeding, it hit a wall when public-employee unions, university students, some individuals within the Catholic Church, small left-wing parties, and the more extreme social-democratic sectors of the PLN mobilized popular opposition against the idea of opening up public-sector monopolies in telecommunications and electric power. Worried PLN legislators responded to this pressure by withdrawing their support from most of the reforms that the Concertación process had already approved. The political costs associated with an intraparty power struggle were too large for moderates among PLN elected officials to face.

This is all very different from what Lehoucq argues. The increasing difficulty of achieving interparty agreements and the impossibility of getting the Assembly to vote are the barriers that stand in the way of accelerated structural reform and hence of improved prospects for economic growth and poverty alleviation. New parties have been emerging since 2002 primarily because of struggles within the PLN and the Left more broadly. 
Lehoucq is right to say that better-educated voters will demand more sophisticated platforms from parties. But this cannot be the whole story; otherwise, why would the political parties not respond to such a challenge? It is also true that, with the end of the Cold War, ideology has become less important as a determinant of party affiliation and voting behavior. Political debates now revolve around mundane matters such as police efficiency, education, social security, and health care. These are complex technical issues that force politicians to deliver a different message. It is no longer enough simply to wave the flag of freedom and democracy; details must be explained, which can be hard to do while remaining popular and attractive to the electorate. But again, this cannot be the explanation for the deterioration of the political climate in Costa Rica, for the same evolution has taken place in other countries without a similar slippage being observed.

Finally, I also agree with Lehoucq that Costa Rica needs new laws and institutions better suited to meeting the expectations of our fellow citizens and the other demands of the new political age in which we find ourselves. This is why in 2001 I proposed a constitutional reform that would have moved us from a presidential to a semipresidential system. My hope in suggesting this change was to force an alignment between the executive and legislative branches that would be strong enough to break the impasse which currently exists between competing political groupings. Taking up this reform proposal again would represent a good start toward answering the political challenges that Costa Rica faces today.

Miguel Angel Rodríguez, Echeverría served as president of Costa Rica from 1998 to 2002, having been elected on the ticket of the Social Christian Unity Party. He was secretary-general of the Organization of American States from June to October 2004.

\section{Endnotes}

1. Fabrice Lehoucq, "Costa Rica: Paradise in Doubt," Journal of Democracy 16 (July 2005): 152. Among the examples of "recent scandals," Lehoucq mentions the criminal investigation that I currently face. I have no quarrel with that, but feel that a few comments are in order. Readers should understand that, as of this writing in February 2006, no prosecutor has filed any formal charges against me. I still do not know what if any charges will be presented in court, or when this will occur. The only "evidence" against me is the testimony of José Antonio Lobo, a person who has already confessed to corruption and dishonesty while a member of the Board of Directors of ICE, the power and telecommunications government company that had awarded the contract. In late 2004, I resigned my post as secretary-general of the Organization of American States (OAS) and voluntarily returned to Costa Rica in order to defend myself in court, informing the attorney-general's office of my desire to refute any charges against me. Readers should also know, finally, about the gross violations of my constitutional and legal rights that I have suffered. Against the express limitation established by the court not to detain me until I had completed my term as secretary-general of the OAS, I was arrested while still holding that post. In clear violation of my human rights, I was considered guilty before trial. On my return, I was subjected to illegal psychological torture, public exhibition, and cruel treatment. As the Judicial Inspection Office has confirmed, the Office of the Prosecutor has illegally violated the confidentiality of the investigation procedures and has furnished them repeatedly to the press so 
as to make me appear guilty. Notwithstanding my voluntary resignation and return, I was in jail and under house arrest for a year with no valid reason.

2. It is important to note that, notwithstanding the difficult political circumstances, Costa Rica continued to make significant accomplishments between 1990 and 2002. Economic growth was stronger than it was in the rest of Latin America, with growth in export income and foreign direct investment particularly robust. Moreover, poverty, infant mortality, and illiteracy continued to fall while life expectancy rose. Finally, the country enacted substantial reforms in the areas of social security and social policy, including laws promoting the rights of labor and the duties of responsible fatherhood.

3. Fabrice Lehoucq, "Costa Rica: Paradise in Doubt," 144. 


\title{
Exchange: Different Times, Different Demands
}

\author{
By: Fabrice Lehoucq
}

Article Reply. "Different Times, Different Demands," Journal of Democracy, Vol. 17, No. 2 (April 2006): 165-7).

I am flattered that former Costa Rican president Miguel Angel Rodríguez (1998-2002) has written a comment on my essay about his country's political travails. His standing as an important economist, together with his longtime involvement in the public affairs of his country, makes his observations of great interest. I hope that his comment is a harbinger of a political memoir of his involvement in public affairs.

President Rodríguez claims that my argument is self-contradictory. While I credit the party system with producing the agreements that have helped the country, for example, to increase its GDP per capita threefold since the 1950s, I also indict that same party system for being unable to continue forging agreements to solve development problems by the 1990s. "How can something that had been present for many decades," President Rodríguez quite reasonably asks, "suddenly become the cause of recent problems?"

President Rodríguez's reflections are especially relevant because something clearly has gone awry in Costa Rica. To begin with, the legislature's ability to pass laws in a reasonably expeditious fashion ("legislative productivity") has fallen to long-term lows during the minority government of President Abel Pacheco (2002-2006), even once we control for the way in which the ban on consecutive terms leads to the productivity-sapping decay of presidential powers by the third year of the political cycle.

Moreover, bureaucratic agencies are not performing very well. Social policy has been unable to reduce the share of Costa Ricans living in poverty, which has stayed at around 20 percent of the population since the mid-1980s. While the public-health system did manage to lower infantmortality rates to developed-world levels by the 1970s, it is been much less successful at providing more advanced health care on a timely basis. Though Costa Rica's development performance remains superior by developing-world standards, the country's ability to maintain and build upon past successes is in doubt. In 2005, the World Economic Forum ranked Costa Rica as having the $64^{\text {th }}$ most competitive economy in the world, a fall of 14 places since 2004. The 2006 Bertelsmann Management Index, a composite measure of the ability of a political system to forge consensus, has Costa Rica slipping from $8^{\text {th }}$ to $19^{\text {th }}$ place since 2003.

While no single factor is responsible for the political system's decline, some factors are more influential than others. The deterioration of policy-making effectiveness flows from a profound crisis of political representation, one that institutional weaknesses also fuel (and that less than impressive economic-growth rates do not help). There is nothing contradictory about recognizing that, in the aftermath of the 1948 civil war and the politically turbulent decade of the 1950s, agreement among party elites laid the basis for several decades of sustained growth and that, by the 1990s, the hierarchically organized party system was no longer conducive to effective policy making in a radically changed society. 
As my essay explained, the party system that a previously less educated and more rural electorate had unabashedly supported between the 1950s and the 1970s was becoming increasingly unpopular by the 1990s. From the mid-1980s to the early 2000s, the share of independents among registered voters more than doubled, going from 17 to 40 percent. President Rodríguez's PUSC obtained less than 4 percent of the vote in the February 2006 elections, while newly elected President Oscar Arias of the PLN, who barely cleared the 40 percent threshold needed for a first-round win, will have to work hard to prevent his own party from suffering a similar fate in a multiparty Assembly.

Narrow local interests continue to dominate internal party affairs enough to inhibit the parties' ability to act as effective transmission belts between citizens and the state. The failure of parties to modernize and to open up policy making (the lack of roll-call votes, among other things, makes it hard to hold deputies accountable) helps to explain why Costa Ricans hold their political class in such low regard. Indeed, the recent scandals that landed two former presidents in jail are nothing more than the climax of a political narrative that citizens and the state have been writing for more than a decade.

Declining legislative productivity has much more to do with this crisis of political representation than it has to do with 1981 procedural changes that President Rodríguez so insightfully discusses. Eliminating the ability of a two-thirds majority in the Assembly to end debate and to call for a vote on an issue has undoubtedly made reaching agreements harder. Indeed, this rulealong with the ability of ten or so deputies to ask the Constitutional Court to judge the constitutionality of any bill-empowers partisan minorities to obstruct lawmaking. This is especially true in fragmented legislatures, which, as the 2002 and 2006 legislative results confirm, are here to stay in Costa Rica.

Yet this rule did not prevent President Rodríguez from reaching an agreement with the opposition PLN to open up telecommunications and electricity to private-sector involvement in 2000. What unfortunately killed these far-reaching reforms (known as "Combo 2000") was that the public never really supported them. The existence of a bipartisan agreement "to betray the national interest," as street protesters must have phrased it, only confirmed to many citizens how out of touch their political class was with their concerns.

In retrospect, Combo 2000 symbolically marks the end of the post-civil war style of policy making, in which the political class made decisions (many of them good ones) behind closed doors and with support but not necessarily much input from the citizenry. Indeed, the Rodríguez administration's use of extralegislative committees to build consensus among NGOs, interest groups, and ordinary citizens marks an important (and welcome) shift toward a more open and participatory style of policy making.

One final point: I share the grief of many Costa Ricans that a remarkable man landed in jail because of accusations of bribe-taking made by a former confidant. In my article, I made it clear that no court has yet convicted President Rodríguez of any charges. To his credit, he resigned his post as secretary-general of the Organization of American States in order to voluntarily return to 
his country to face these accusations. I wish him (and Costa Rica) a fair and speedy trial plus the best of luck. 